\title{
Effectiveness of the English Writing Process for Post-secondary School Students
}

\author{
Yang Silin (Corresponding author) \\ Centre for Educational Development, Republic Polytechnic \\ 9 Woodlands Avenue 9, Singapore 738964, Singapore \\ Tel: (+65) 66971013 E-mail: yang_silin@rp.edu.sg \\ Andrea Chan \\ Centre for Educational Development, Republic Polytechnic \\ 9 Woodlands Avenue 9, Singapore 738964, Singapore \\ Tel: (+65) 66971562 E-mail: andrea_chan@rp.edu.sg
}

Received: February 18, 2015 Accepted: March 26, 2015 Published: March 26, 2015

doi:10.5296/ijele.v3i1.7327 URL: http://dx.doi.org/10.5296/ijele.v3i1.7327

\begin{abstract}
With the intention of contributing to the current state of knowledge about the writing skills of Singapore students, a study was carried out on a group of 73 post-secondary students in a polytechnic. The students are mandated to undertake an English Language and Communication module which aims to strengthen their core English Language proficiency. The aims of the study reported in this paper are: (a) to examine the differences in the levels of writing skills of the post-secondary students before and after completion of the English Language and Communication module, and (b) to investigate students' perceptions of the English Language and Communication module. The study compared the compositions written by the students at the start and end of the module in terms of vocabulary, fluency, clarity and organisation, and overall composition levels. A scoring rubric, based on an evaluation rubric used by the Ministry of Education Singapore (2010), was developed to grade these compositions. Based on the analysis of the data, it was found that the students' writing skills improved significantly. The study also administered a questionnaire to elicit the students' perceptions on the usefulness of the module in the enhancement of their writing skills. The questionnaire analysis corroborates with our findings that the module is effective in enhancing the writing skills of post-secondary students. The findings, in the light of writing process method and recommendations for future research study, are discussed.
\end{abstract}

Keywords: Writing Process, English Language, Post-secondary Students, Polytechnic 


\section{Introduction}

Singapore is a linguistically and ethnically diverse country with a population of more than 5 million. Given this diverse linguistic landscape, bilingualism has always been a cornerstone of Singapore's education system. The bilingual policy was officially introduced in 1960s. Under this bilingual policy, the main medium of instruction in school is English, and all students learn an official Mother Tongue Language (Chinese, Malay and Tamil). In the Report of the English Language Curriculum and Pedagogy Review published by Ministry of Education Singapore in 2006, it was noted that although Singapore students do fairly well in reading literacy, standards of oral and written communication are highly uneven. Focus group discussions with employers also revealed that that there had been a decline in the writing skills of their employees (Ministry of Education Singapore, 2006). One of the key desired outcomes identified by the Ministry of Education is hence to allow our students to develop a good level of competence in English Language, in both speech and writing (Ministry of Education Singapore, 2010).

Similarly, in today's context, the ability to write proficiently gives one the power and opportunity to share and influence thoughts, ideas, and opinions with others, not only in day-to-day situations, but also across time and space. The value that we place on reading and writing arises out of our shared need to be literate, which is a function of our society and of our culture (Heller, 1999). Writing is more than merely a means of communication, and it extends to influence functional and cultural aspects in society. In spite of the importance of writing, to date, there is little research to study the writing skills of post-secondary students in a bilingual environment.

With the intention of contributing to the current state of knowledge about the writing skills of post-secondary students, a study has been carried out on a group of 73 post-secondary students in a polytechnic in Singapore. These students are mandated to undertake an English Language and Communication module in the institution. This module aims to strengthen students' core English Language proficiency while building their confidence for public communication in both the written and oral forms. Lecturers in this institution have adapted the writing process model as proposed by Flower and Hayes $(1980,1981)$ for this purpose. The students are required to go through the four stages of writing: pre-writing, drafting, editing, and rewriting in the writing process.

The aims of the study reported in this paper therefore are: (a) to examine the differences in the levels of writing skills of the post-secondary students before and after completion of the English Language and Communication module, and (b) to investigate students' perceptions of the English Language and Communication module. The findings of this study provided insights into the four-stage writing process adopted by the polytechnic which has shown to be effective in improving the writing skills of post-secondary students.

\section{Literature Review}

\subsection{Background to Singapore Education System}

Education plays a central role in shaping Singapore's development. From the 
post-independent years of nation-building in cultivating a coherent and "strong civic ideology" among racial communities (Green, 1997) to adopting pragmatic policies in developing the young nation state's economic capital and viability, Singapore has consistently transformed its education system to meet changing landscapes.

The bilingual policy was officially introduced in 1960s and since then, bilingualism is a cornerstone of the education system in Singapore. Under this policy, English is being taught as the first language and is also the medium of instruction in the schools. Therefore the Ministry of Education in Singapore places heavy emphasis on the learning of English. It is the common language that facilitates bonding among the different ethnic and cultural groups. In addition, it also allows Singaporeans to participate in a knowledge-based economy where English is the lingua franca of the Internet, of science and technology and of world trade. Proficiency in English is viewed as being necessary for students to access, process and keep abreast of information, and to engage with the wider and more diverse communities outside of Singapore (Ministry of Education, 2010).

In the Report of the English Language Curriculum and Pedagogy Review published by Ministry of Education Singapore in 2006, it was mentioned that there is a wide range of English language proficiency among the students in Singapore. One of the key desired outcomes identified by the Ministry of Education would be to develop the competence of students in the English Language, in both speech and writing (Ministry of Education Singapore, 2006).

\subsection{English Writing Process}

The technical aspects of proper grammar, spelling, punctuation, and other conventions were a principal focus in teaching writing in the past (Hillocks, 1987). However, this approach soon came under increasing scepticism because it failed to engage students in their learning (Hicks, 1993; Hillocks, 1986). Several studies conducted have shown that the teaching and learning of formal, traditional grammar had no effect on the quality of students' writing, and that the teaching of grammar may actually hinder the development of students' English (Macaulay, 1947; Braddock, Lloyd-Jones, \& Schoer, 1963). Since then, responding to the need for innovative instruction and teaching pedagogies, there was a need to move beyond rote repetition and technical instruction. Rather than focusing on spelling, grammar, and other writing conventions, educators started to place their emphasis on the actual process of writing.

Gordon Rohman introduced the Pre-Write/Write/Re-Write model in 1965, and James Britton Britton introduced The Conception/Incubation/Production model in 1975. These models describe the writing process as a linear series of stages, separated by time, and characterised by the gradual development of the written product. The introduction of these models helped to improve the teaching of writing by highlighting the importance of planning in the writing process. However, these models soon came under criticism by educators over whether it was an accurate description of the writing process. Since 1980, Flower and Hayes have proposed a number of models of the writing process. The development of their second model (see Figure 1) in 1981 has since then been widely adopted by many educators. It should be 
acknowledged that the model which was developed in 1981 was more or less similar and predominantly based upon the idea of their original 1980 model. In this model, the act of writing involves three major elements: (a) task environment; (b) writer's long-term memory; and (c) writing process. It concentrates on writing as a recursive process in which writers have the opportunity to plan, draft, edit, and revise their work (Hillocks, 1987). The writer is taught to review and revise several drafts, which enables and encourages new ideas. Grammatical changes and conventional editing occur during the revision or editing stage (Ballator, Farnum, \& Kaplan, 1999; Flower \& Hayes, 1981). Furthermore, since grammar and conventions are not the focus of writing, the writing process may be adapted for use even with young writers in kindergarten (Sealey, Sealey, \& Millmore, 1979). To date, studies indicate that the writing process is one effective way to teach students to be good writer (Flower \& Hayes, 1981; Greenwald, Persky, Campbell, \& Mazzeo, 1999; Graham \& Harris, 2000; Unger \& Fleischman, 2004; Cavkaytar \& Yasar, 2008).

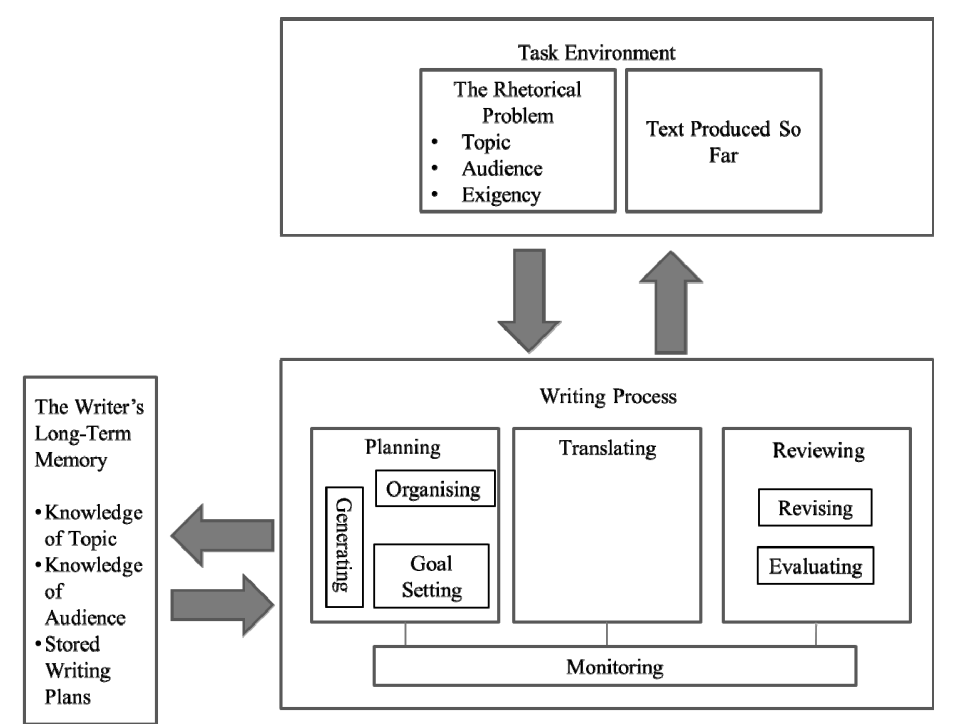

Figure 1. Flower \& Hayes' (1980) model of the writing process

\section{Method}

\subsection{Ethical considerations}

This research study was approved by the Ethics Review Committee at the institution where the research was conducted. The accepted research protocol included informed consent by the survey participants, controlled storage and access of data, and de-identified data for analysis.

\subsection{Participants}

Participants involved in the study were 73 post-secondary students of an English Language and Communication module in a polytechnic in Singapore. They belonged to the top $10 \%$ of the Secondary 4 Normal Academic (NA) cohort, and were given provisional places in polytechnic diploma programmes. 
Among these 73 students, $22 \%$ of the students obtained a Grade 1, 46\% of the students obtained a Grade 2, while $32 \%$ of the students obtained a Grade 3 for their English GCE 'Normal' Level results. Based on a survey that was conducted at the start of the semester, most of the students $(64 \%)$ spend less than 1 hour on reading each day, with only $1 \%$ of the students spending more than 7 hours on reading each day.

\subsection{Educational Context}

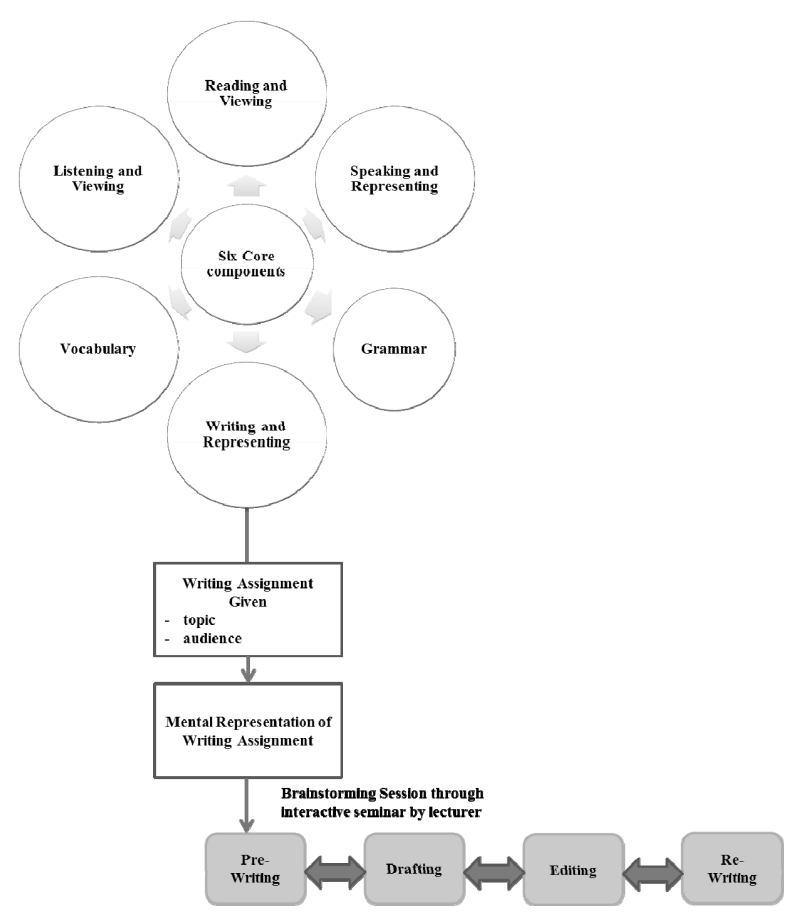

Figure 2. English Language and Communication Module

Figure 2 describes the six key components of the English Language and Communication Module in a polytechnic in Singapore. This module aims to strengthen students' core English Language proficiency while building their confidence for public communication in both the written and oral forms. It comprises Reading and Viewing, Listening and Viewing, Speaking and Representing, Writing and Representing, Grammar and Vocabulary. Each of these components is essential to improving the literacy level of post-secondary students.

The key component of Writing and Representing is fundamental to developing the students' writing ability. Teachers' awareness of the writing process will be helpful in teaching appropriate strategies and improving the students' writing abilities in an education environment (Kapka \& Oberman, 2001). Lecturers in this polytechnic have adopted and adapted the writing process model as proposed by Flower and Hayes (1980, 1981), with the students required to go through the four stages of pre-writing, drafting, editing and rewriting in the writing process.

\subsubsection{Pre-Writing}

Pre-writing, or planning what is going to be written, is an essential step in the writing process 
and should account for $70 \%$ of the writing time (Murray, 1982). In this stage, students are required to plan before any form of writing takes place. Often, students tap on their prior knowledge and any forms of research information with reference to the topic given by the teacher at the start of the lesson. This allows them to have the necessary content and information to begin writing.

\subsubsection{Drafting}

This is essentially the process of putting ideas into visible language. In the drafting stage, students put into writing the information they had gathered via the pre-writing stage. In this stage, spelling rules for the written text are ignored. If the writer must devote conscious attention to demands such as spelling and grammar, the task of drafting may be affected as this extra burden of noting the technical aspects of the written English may be too overwhelming for the students (Flower \& Hayes, 1981).

\subsubsection{Editing}

This editing stage is a conscious process in which teachers and peers provide feedback for students to improve on their writing. Students then edit their writing in accordance to the comments provided by their teachers and peers. Through peer editing, it teaches them to recognise the value of writing and the purpose in creating a solid and substantial work (Graves, 1983). This period of editing frequently leads to new cycles of pre-writing and drafting to incorporate the new ideas. Students will take this opportunity to revisit their goals and plans for writing. At this stage, students are conscious of the technical aspects of text used in the piece of writing.

\subsubsection{Rewriting}

Rewriting is the last stage of the writing process where students submit the completed paper after rewriting it.

The aim of the study is therefore to examine the differences in the levels of writing skills of the post-secondary students before and after completion of the English Language and Communication module, and to investigate students' perceptions of the English Language and Communication module by comparing the compositions written by the students at the start of the module and at the end of the module.

\subsection{Data Collection}

The study used a pre-test/post-test design, which was based on the first and final piece of students' compositions completed in the English Language and Communication module. The students were required to write an academic text of about 400 words mainly in a narrative form. The main source of data for this study was compositions written in the English Language and Communication module at the start and end of the semester.

\subsection{Analysis}

Analysis was carried out on the first and final piece of students' compositions completed in the English Language and Communication module. Firstly, it aimed to ascertain whether 
students' proficiency in writing had improved purely in numerical terms. Thereafter, a more detailed analysis of students' composition, focusing on vocabulary, fluency, clarity, and organisation was carried out.

A scoring rubric, based on an evaluation rubric (as attached in the appendix) used by the Ministry of Education Singapore (2010), was developed to grade these compositions. The rubric assessed the mastery of language use in terms of the range of vocabulary, fluency, clarity, and organisation demonstrated. There are four levels in the rubric: Level 4 being the lowest proficiency level while Level 1 being the highest. In addition, these students were also asked to sign a consent form and complete a questionnaire on (a) the usefulness of the English Language and Communication module in the enhancement of their writing skills, (b) three most useful ideas that they have learned in the module, (c) ways they have applied the useful ideas learned in the module, and (d) any aspect of the module that can be improved. Students participating in the research were assured of anonymity and all individual data were de-identified in the data set for analysis.

\section{Results}

\subsection{Quantitative Analysis of Students' Composition}

Based on the analysis of the data, the comparison between the first and the final composition written by the 73 post-secondary students suggests that the four-stage writing process has improved and developed the students' writing abilities. Table 3 shows the mean scores and standard deviations for student composition in the pre-test and post-test for the various components. There was an overall improvement in the quality of writing exhibited in the post test, that is, students seemed to attain a higher level of performance in terms of vocabulary, fluency, clarity, and organisation. A paired-samples t-test was also conducted to compare the mean score of the first composition with the last. Results from the paired sample t-test showed that there was a significant difference in the mean score for the pre-test $(M=10.99$, $\mathrm{SD}=3.13)$ and post-test $(\mathrm{M}=9.05, \mathrm{SD}=2.18), \mathrm{t}(72)=9.10, \mathrm{p}<0.001$ as shown in Table 3 .

Table 3. Aspect of composition in Pre-test and Post-test

\begin{tabular}{|l|c|c|c|c|c|c|c|}
\hline \multirow{2}{*}{ Aspect of composition } & \multicolumn{2}{|c|}{ Pre-test } & \multicolumn{2}{c|}{ Post-test } & \multirow{2}{*}{$t$} & $p$ & $d$ \\
\cline { 2 - 7 } & $M$ & $S D$ & $M$ & $S D$ & & & \\
\hline Vocabulary & 2.81 & 0.908 & 2.38 & 0.592 & 6.06 & $<0.001$ & 0.573 \\
\hline Fluency & 2.74 & 0.913 & 2.21 & 0.666 & 7.3 & $<0.001$ & 0.671 \\
\hline Clarity & 2.71 & 0.874 & 2.25 & 0.641 & 7.17 & $<0.001$ & 0.607 \\
\hline Organisation & 2.73 & 0.804 & 2.22 & 0.651 & 7.17 & $<0.001$ & 0.701 \\
\hline $\begin{array}{l}\text { Overall composition } \\
\text { level }\end{array}$ & 10.99 & 3.13 & 9.05 & 2.18 & 9.1 & $<0.001$ & 0.730 \\
\hline
\end{tabular}




\subsubsection{Appropriate Use of Varied Vocabulary}

Use of vocabulary is an important aspect of composition writing. Each student's writing was given a level of 1-4 for the ability to use appropriate and varied vocabulary based on the rubrics, Level 4 being the lowest proficiency level while Level 1 being the highest. Table 4 shows the number of students organised according to the different levels for the use of varied vocabulary in the pre-test and post-test. Although there was no improvement in the number of students in Level 1, there was a distinct improvement in the other levels. With 21 students in Level 4 in pre-test, there was only 1 student left in Level 4 in the post-test. The number of students in Level 2 and Level 3 has also increased from 29 to 40 and 20 to 29 respectively.

Table 4. Results for appropriate use of varied vocabulary in Pre-test and Post-test

\begin{tabular}{|c|c|c|c|c|c|c|c|c|}
\hline & \multicolumn{2}{|c|}{ Level 1 } & \multicolumn{2}{c|}{ Level 2 } & \multicolumn{2}{c|}{ Level 3 } & \multicolumn{2}{c|}{ Level 4 } \\
\hline & $\mathrm{n}$ & $(\%)$ & $\mathrm{n}$ & $(\%)$ & $\mathrm{n}$ & $(\%)$ & $\mathrm{n}$ & $(\%)$ \\
\hline Pre-test & 3 & 4.11 & 29 & 39.73 & 20 & 27.4 & 21 & 28.77 \\
\hline Post-test & 3 & 4.11 & 40 & 54.79 & 29 & 39.73 & 1 & 1.37 \\
\hline
\end{tabular}

\subsubsection{Sentence Fluency and Accuracy}

We measured the sentence structure of the students' composition by looking at the ability to use varied sentence structure and writing flow. Similarly, each student's composition was assigned a level of 1-4 based on the rubrics, Level 4 being the lowest proficiency level while Level 1 being the highest. Table 5 shows the number of students at the different levels for sentence fluency and accuracy in the pre-test and post-test. There was a distinct improvement in level 2. With 27 students in Level 2 in the pre-test, there was an increase of $19.18 \%$, with 41 students attaining Level 2 in the post-test.

Table 5. Results for sentence fluency and accuracy in Pre-test and Post-test

\begin{tabular}{|c|c|c|c|c|c|c|c|c|}
\hline & \multicolumn{2}{|c|}{ Level 1 } & \multicolumn{2}{c|}{ Level 2 } & \multicolumn{2}{c|}{ Level 3 } & \multicolumn{2}{c|}{ Level 4 } \\
\hline & $\mathrm{n}$ & $(\%)$ & $\mathrm{n}$ & $(\%)$ & $\mathrm{n}$ & $(\%)$ & $\mathrm{n}$ & $(\%)$ \\
\hline Pre-test & 5 & 6.85 & 27 & 36.99 & 23 & 31.51 & 18 & 24.66 \\
\hline Post-test & 9 & 12.33 & 41 & 56.16 & 22 & 30.14 & 1 & 1.37 \\
\hline
\end{tabular}

\subsubsection{Clarity of Expression}

Table 6 shows the number of students at the different levels for clarity of expression in the pre-test and post-test. There was an increase, though not statistically significant at $1.37 \%$, in the number of students who obtained level 1 for the component of clarity of expression in the post-test compared with the pre-test. However, there was an obvious improvement in the number of students obtaining Level 2, from 20 students in the pre-test compared to 39 students in the post-test. 
Table 6. Results for clarity of expression in Pre-test and Post-test

\begin{tabular}{|c|c|c|c|c|c|c|c|c|}
\hline & \multicolumn{2}{|c|}{ Level 1 } & \multicolumn{2}{c|}{ Level 2 } & \multicolumn{2}{c|}{ Level 3 } & \multicolumn{2}{c|}{ Level 4 } \\
\hline & $\mathrm{n}$ & $(\%)$ & $\mathrm{n}$ & $(\%)$ & $\mathrm{n}$ & $(\%)$ & $\mathrm{n}$ & $(\%)$ \\
\hline Pre-test & 7 & 9.59 & 20 & 27.4 & 33 & 45.21 & 13 & 17.81 \\
\hline Post-test & 8 & 10.96 & 39 & 53.42 & 26 & 35.62 & 0 & 0 \\
\hline
\end{tabular}

\subsubsection{Organisation}

A close examination of the organisation of ideas in the composition in the pre-test and post-test revealed that there was an improvement in the number of students who obtained Level 1 and Level 2 in the post-test as shown in Table 7, with $12.33 \%$ and $53.42 \%$ of the students obtaining Level 1 and Level 2 respectively. In addition, there were no students who obtained Level 4 in the post-test.

Table 7. Results for organisation in Pre-test and Post-test

\begin{tabular}{|c|c|c|c|c|c|c|c|c|}
\hline & \multicolumn{2}{|c|}{ Level 1 } & \multicolumn{2}{c|}{ Level 2 } & \multicolumn{2}{c|}{ Level 3 } & \multicolumn{2}{c|}{ Level 4 } \\
\hline & $\mathrm{n}$ & $(\%)$ & $\mathrm{n}$ & $(\%)$ & $\mathrm{n}$ & $(\%)$ & $\mathrm{n}$ & $(\%)$ \\
\hline Pre-test & 4 & 5.48 & 24 & 32.88 & 33 & 45.21 & 12 & 16.44 \\
\hline Post-test & 9 & 12.33 & 39 & 53.42 & 25 & 34.25 & 0 & 0 \\
\hline
\end{tabular}

\subsection{Qualitative Analysis of Students' Feedback}

The qualitative questions elicited students' feedback on the usefulness of the English Language and Communication module in the enhancement of their writing skills, namely, the three most useful ideas that they have learned in the module, the ways they have applied the useful ideas learned in the module, and any aspect of the module that can be improved.

\subsubsection{Impact of the Module on Writing Skills}

In response to the open-ended question of the usefulness of the English Language and Communication module, $98 \%$ of the students provided very positive comments on the module. In addition, the students also commented on some of the specific skills that the module has helped them develop, including being aware of the different formats of writing, grammar and vocabulary, as shown in the following examples:

Student A The module has taught me a lot in better expressing my writing. I have learnt different forms of writing skills such as resume, complaint letters, formal letters etc. This will help me a lot in future when I am working in the society in future. The module has also helped me to improve on certain life skills such as evaluation.

Student B It has helped me write an argumentative essay, the things to look out for when writing. I also learned how to write a cover letter, formal and informal letter.

Student $C \quad$ The module has taught me to be more aware of writing. It taught me the techniques of how 
to write a proposal and speech writing.

Student D I've learnt many techniques and how to write a good essay.

Student $E \quad$ The module has taught me to be more aware of the grammar when writing.

Student $F \quad$ It gave me a greater variety of words to use. My vocabulary is better now.

\subsubsection{Application of the useful ideas learned in the module}

While the main aim of the module is to improve students' English proficiency, students are also able to apply the useful ideas learned in the module. The most frequently mentioned is the ability to write a good resume for part-time job applications and the writing of letters. Below are some examples:

\begin{tabular}{ll}
\hline Student $G$ & $\begin{array}{l}\text { I wrote a formal email to teacher, and a complain letter to a shop complaining about faulty } \\
\text { product. }\end{array}$ \\
Student $H$ & I'm writing to other countries to my relatives. \\
Student I & I wrote several formal emails to employers for part time jobs. \\
Student $J$ & I have used the cover letter for my application to part time job. \\
\hline
\end{tabular}

\subsubsection{Aspects of the module that can be improved}

Some students also expressed their thoughts on how the module can be further improved. These improvements include more interactive activities, as well as the introduction of English poetry and literature. Below are some typical comments from the students:

\begin{tabular}{ll}
\hline Student $K$ & More interactive activities such as role-playing. \\
Student $L$ & Make it more interesting by having more activities. \\
Student $M$ & Should to do more activities which is fun and useful. \\
Student $N$ & Perhaps, more of English than communication, with poetry and literature. \\
\hline
\end{tabular}

\section{Discussion}

Our analysis of the compositions written by the students in the pre-test and post-test shows that the four-stage writing process adopted by the polytechnic has been effective in improving the writing skills of post-secondary students, especially students whose proficiency was in Level 4 in the pre-test. However, the number of students who obtained Level 1 in the post-test was not significantly higher compared to pre-test.

The questionnaire analysis corroborates our findings on the effectiveness of the English Module in improving their writing skills to a limited extent as majority of the students found the course to be useful in the enhancement of their writing skills. They were also able to apply the skills learnt to their daily lives. Nevertheless, we are also aware that there are areas in which the module can be improved. Students expressed their wish for more interactive and interesting activities to be incorporated into the lesson. Thus, overall, the module seems to 
have achieved one of the objectives it set out to achieve, i.e., in improving the writing skills of the students. One key limitation of this study is the small sample size, which may not be representative of all post-secondary students.

Based on the results from the compositions that number of students who obtained Level 1 in the post-test was not significantly higher compared to the pre-test, it is recommended that educators can leverage the knowledge of the transformation model of writing to further enhance the teaching of English writing, which places strong emphasis on the planning stage, and to develop novice into expert writers. Based on the knowledge-transforming model, writing assignments require not only knowledge-telling but also the process of knowledge-transforming. An expert writer will employ a knowledge-transforming strategy, which involves elaborating a representation of the rhetorical or communicative problem to be solved and using the goals derived from this representation to guide the generation and evaluation of content during writing, and the end result is that the quality of writing by the expert writer is definitely higher than the novice writer (Galbraith, 1999). More specifically, this can be a direction for the next research study, with a larger representative sample size.

\section{Acknowledgements}

We would like to thank the Centre for Enterprise and Communication, Republic Polytechnic for their support in this study. We would also like to thank Helena Lim, Leyana Ibrahiman and Gini Thomas for collecting the data and encouraging their students to participate in this study.

\section{References}

Ballator, N., Farnum, M., \& Kaplan, B. (1999). 1996 Trends in Writing. National Center for Education Statistics, 1(2), 28.

Braddock, R., Lloyd-Jones, R., \& Schoer, L. (1963). Research in Written Composition. Champaign, IL: National Council of Teachers of English.

Cavkaytar, S., \& Yasar, S. (2010). Using Writing Process in Teaching Composition Skills: an Action Research. Paper presented at the ICT for Language Learning International Conference, Florence.

Deng, X., Lee, K., Chitra, V., \& Lim, M. (2010). Academic Writing Development of ESL/EFL Graduate Students in NUS. Reflections on English Language Teaching, 9(2), 119-138.

Flower, L., \& Hayes, J. R. (1980). The Cognition of Discovery: Defining a Rhetorical Problem. College Composition and Communication, 31(1), 21-32. http://dx.doi.org/10.2307/356630

Flower, L., \& Hayes, J. R. (1981). A Cognitive Process Theory of Writing. College 
Composition and Communication, 32(4), 365-387. http://dx.doi.org/10.2307/356600

Galbraith, D. (1999). Writing as a Knowledge-Constituting Process. In M. Torrance , \& D. Galbraith, Knowing What to Write: conceptual processes in text production (pp. 139-160). Amsterdam, NL: Amsterdam University Press.

Galbraith, D., Ford, S., Walker, G., \& Ford , J. (2005). The Contribution of Different Components of Working Memory to Knowledge Transformation During Writing. L1-Educational Studies in Language and Literature, 5(2), 113-145. http://dx.doi.org/10.1007/s10674-005-0119-2

Graham, S., \& Harris , K. R. (2000). The Role of Self-Regulation and Transcription Skills in Writing and Writing Development. Educational Psychologist, 35(1), 3-12. http://dx.doi.org/10.1207/S15326985EP3501_2

Graves, D. H. (1983). Writing: Teachers and children at work. Heinemann Educational Books, 4 Front St., Exeter, NH 03833.

Green, A., 1997. Education, globalisation and the nation state. Basingstoke: Macmillan. http://dx.doi.org/10.1057/9780230371132

Greenwald, E. A., Persky, H. R., Campbell, J. R., \& Mazzeo, J. (1999). NAEP 1998 Writing Report Card for the Nation and the States. ED Pubs, PO Box 1398, Jessup, MD 20794-1398.

Hayes, J. R. (1996). A new framework for understanding cognition and affect in writing. In C. M. Levy, \& S. Ransdell, The Science of Writing: Theories, Methods, Individual Differences and Applications (pp. 1-27). Mahwah, NJ: Lawrence Erlbaum Assoc.

Heller, M. F. (1999). Reading-writing connections from theory to practice. Mahwah, N.J.: Lawrence Erlbaum Associate.

Hicks, J. R. (1993). Let's get serious about teaching children to write. Lanham: University Press of America.

Hillocks, G. (1986). Research on written composition: new directions for teaching. New York, N.Y.: National Conference on Research in English.

Hillocks, G. (1987). Synthesis of research on teaching writing. Educational Leadership, 44(8), 71-82.

Kapka, D., \& Oberman, D. A. (2001, 4 1). Improving Student Writing Skills through the Modeling of the Writing Process. Retrieved from ERIC Clearinghouse: http://www.eric.ed.gov/contentdelivery/servlet/ERICServlet?accno=ED453536

Macauley, W. J. (1947). The difficulty of grammar. British Journal of Educational Psychology, 17(3), 153-162. http://dx.doi.org/10.1111/j.2044-8279.1947.tb02223.x

Ministry of Education Singapore. (2006). Report of the English Language Curriculum and Pedagogy Review. Retrieved from http://www.tesol.edu.sg/pdf/MOE\%20English\%20Review.pdf 
Ministry of Education Singapore. (2010). English Language Syllabus 2010. Retrieved from http://www.moe.gov.sg/education/syllabuses/english-language-and-literature/files/english-pri mary-secondary-express-normal-academic.pdf

Murray, D. M. (1982). Learning by Teaching: Selected Articles on Writing and Teaching. Boynton/Cook Publishers, Inc., 206 Claremont Ave., Montclair, NJ 07042.

Sealey, L., Sealey, N., \& Millmore, M. (1979). Children's Writing: An Approach for the Primary Grades. Newark, N.J.: International reading Association.

Unger, J., \& Fleischman, S. (2004). Research Matters/Is Process Writing the" Write Stuff"?. Writing, 62(2).

Appendix 1. Scoring Rubric

\begin{tabular}{|c|c|c|c|c|}
\hline & Level 1 & Level 2 & Level 3 & Level 4 \\
\hline $\begin{array}{l}\text { A) Appropriate } \\
\text { use of varied } \\
\text { vocabulary }\end{array}$ & $\begin{array}{l}\text { - Powerful and } \\
\text { engaging words } \\
\text { carefully selected to } \\
\text { convey the intended } \\
\text { impression in a } \\
\text { precise, interesting } \\
\text { an natural } \\
\text { way-phrases create } \\
\text { pictures } \\
\text { - Linger in } \\
\text { reader's mind }\end{array}$ & $\begin{array}{l}\text { - Wide and } \\
\text { precise } \\
\text { enough to } \\
\text { convey } \\
\text { intended } \\
\text { shades of } \\
\text { meaning } \\
\text { - Uses a mix } \\
\text { of precise } \\
\text { and general } \\
\text { verbs } \\
\text { - Some } \\
\text { striking } \\
\text { language is } \\
\text { evident }\end{array}$ & $\begin{array}{l}\text { - Vocabulary } \\
\text { used are } \\
\text { adequate } \\
\text { and correct } \\
\text { - Lack of } \\
\text { originality }\end{array}$ & $\begin{array}{l}\text { - Simple } \\
\text { vocabulary } \\
\text { usually } \\
\text { adequate to } \\
\text { convey } \\
\text { intended } \\
\text { meaning } \\
\text { - Errors may } \\
\text { occur with } \\
\text { more } \\
\text { ambitious } \\
\text { words }\end{array}$ \\
\hline $\begin{array}{l}\text { B) Sentence } \\
\text { fluency \& } \\
\text { accuracy }\end{array}$ & $\begin{array}{l}\text { - Well-constructed } \\
\text { with strong and } \\
\text { varied sentence } \\
\text { structure, created } \\
\text { for particular } \\
\text { effects } \\
\text { - Natural flow in } \\
\text { the writing }\end{array}$ & $\begin{array}{l}\text { - Some flaws } \\
\text { in writing } \\
\text { are } \\
\text { evident-uses } \\
\text { a variety of } \\
\text { sentence } \\
\text { beginnings, } \\
\text { structures } \\
\text { and length } \\
\text { - Natural } \\
\text { fluency is }\end{array}$ & $\begin{array}{l}\text { - Some } \\
\text { variety of } \\
\text { sentence } \\
\text { structure } \\
\text { and length, } \\
\text { not always } \\
\text { for } \\
\text { particular } \\
\text { purpose }\end{array}$ & 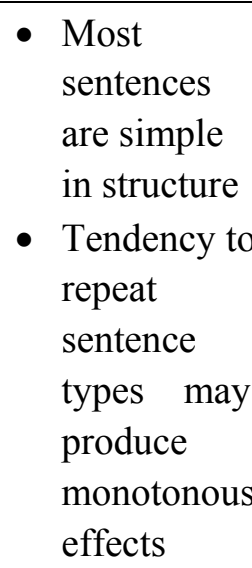 \\
\hline
\end{tabular}




\begin{tabular}{|c|c|c|c|c|}
\hline & & $\begin{array}{l}\text { created by } \\
\text { the variation } \\
\text { in sentence } \\
\text { structure }\end{array}$ & & \\
\hline $\begin{array}{l}\text { C) Clarity of } \\
\text { expression }\end{array}$ & $\begin{array}{l}\text { - } \text { Clear and } \\
\text { focused } \\
\text { - Relevant } \\
\text { anecdotes and } \\
\text { details } \\
\text { enrich central } \\
\text { themes } \\
\text { - Fresh, } \\
\text { original treatment } \\
\text { of } \\
\text { ideas }\end{array}$ & $\begin{array}{l}\text { - Writing is } \\
\text { mainly } \\
\text { focused } \\
\text { - Most } \\
\text { information is } \\
\text { relevant and } \\
\text { supports } \\
\text { the themes } \\
\text { - Provides } \\
\text { main idea, } \\
\text { but details } \\
\text { are general } \\
\text { or brief }\end{array}$ & $\begin{array}{l}\text { - } \text { Adequate } \\
\text { but } \\
\text { mundane } \\
\text { treatment of } \\
\text { ideas } \\
\text { - Some } \\
\text { attempt at } \\
\text { support or } \\
\text { expansion, } \\
\text { but no } \\
\text { details } \\
\text { provided for } \\
\text { key issues }\end{array}$ & 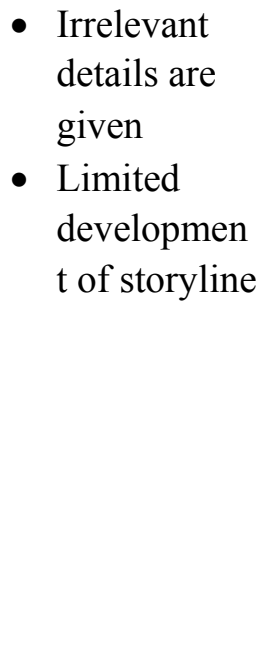 \\
\hline D) Organisation & $\begin{array}{l}\text { - Order, structure } \\
\text { of presentation or } \\
\text { information is } \\
\text { compelling and } \\
\text { moves the reader } \\
\text { through the text } \\
\text { - Inviting } \\
\text { introduction and } \\
\text { satisfying } \\
\text { conclusion } \\
\text { - Well planned } \\
\text { transitions } \\
\text { between ideas }\end{array}$ & $\begin{array}{l}\text { - Structure } \\
\text { moves } \\
\text { reader } \\
\text { through the } \\
\text { text } \\
\text { adequately } \\
\text { - Introduction } \\
\text { and } \\
\text { conclusion } \\
\text { are evident } \\
\text { - Clear } \\
\text { transitions } \\
\text { between } \\
\text { ideas }\end{array}$ & $\begin{array}{l}\text { - Structure is } \\
\text { confusing at } \\
\text { times } \\
\text { - May lack } \\
\text { introduction } \\
\text { or } \\
\text { conclusion } \\
\text { - Weak } \\
\text { transition } \\
\text { between } \\
\text { ideas }\end{array}$ & $\begin{array}{l}\text { - Nonexistent } \\
\text { lead and } \\
\text { conclusion } \\
\text { - Transition } \\
\text { between } \\
\text { ideas may } \\
\text { be absent or } \\
\text { inappropriat } \\
\text { e }\end{array}$ \\
\hline
\end{tabular}

\section{Copyright Disclaimer}

Copyright for this article is retained by the author(s), with first publication rights granted to the journal.

This is an open-access article distributed under the terms and conditions of the Creative Commons Attribution license (http://creativecommons.org/licenses/by/3.0/). 